\title{
PEMBUATAN DAN UJI ORGANOLEPTIK SEDIAAN MINUMAN SERBUK INSTAN DAUN PEPAYA (Carica papaya L.) DAN KACANG HIJAU (Vigna radiata L.) UNTUK MEMPERLANCAR PRODUKSI AIR SUSU IBU (ASI)
}

\author{
Diaz Ananda Widianto ${ }^{*}$, Elih Sutisna Yanto ${ }^{2}$, Reti Puji Handayani ${ }^{3}$ \\ ${ }^{123}$ sekolah Tinggi Ilmu Kesehatan Holistik
}

*Korespondensi: Jalan Veteran No 272 Ciseureuh Purwakarta, Email: diaz.anandawidianto10@gmail.com

\begin{abstract}
ABSTRAK
Latar Belakang: ASI (Air Susu Ibu) adalah suatu emulsi lemak dalam larutan protein, laktose dan garam-garam organik yang disekresi oleh kedua belah kelenjar payudara ibu, sebagai makanan utama bagi bayi. Sekarang ini banyak ibu yang memberikan ASI kurang dari enam bulan karena beberapa faktor seperti bayi sakit, lelah bekerja dan stress, sehingga produksi ASI tidak lancar dan lain-lain. Daun pepaya mengandung beberapa nutrisi penting, beberapa penelitian telah dilakukan, Entin (2002) yang membuktikan bahwa daun katuk, daun pare, dan daun pepaya merupakan suplemen yang merupakan tanaman tradisional dan memiliki potensi meningkatkan produksi air susu ibu4. Kacang hijau juga mengandung senyawa aktif yaitu polifenol dan flavonoid yang berfungsi meningkatkan hormon produksi ASI.

Tujuan: Membuat sediaan minuman serbuk instan dan stabilitas dalam uji organoleptik selama tiga minggu dengan pemanfaatan tumbuhan daun pepaya (Carica papaya L.) dan Kacang Hijau (Vigna radiata L.) untuk memperlancar produksi air susu ibu (ASI) dengan pembuatan yang mudah dan praktis.

Metode: Penelitian ini menggunakan disain penelitian tindakan (action research). Sediaan dengan formulasi gula yang berbeda, yaitu F1 daun pepaya 5 gram, kacang hijau 41,6 gram, gula 60 gram. F2 daun pepaya 5 gram, kacang hijau 41,6 gram, gula 90 gram. Dan F3 daun pepaya 5 gram, kacang hijau 41,6 gram, gula 120 gram. Sampel di simpan dalam penyimpanan yang sama, yaitu dalam suhu ruangan $20-25^{\circ} \mathrm{C}$.

Hasil: Menunjukkan bahwa sediaan minuman serbuk instan daun pepaya dan kacang hijau yang disimpan pada suhu ruangan $20-25^{\circ} \mathrm{C}$ memiliki stabilitas organoleptik bentuk, bau, dan warna.

Simpulan: Dari hasil pengujian orgnaloleptik dihasilkan 3 sediaan dengan rasa yang sedikit berbeda salah satunya mempunyai rasa yang lebih enak yaitu rasanya tidak terlalu manis serta tidak terlalu pahit sediaan ini dapat bertahan selama tiga minggu dengan keadaan fisik yang relatif tidak berubah.
\end{abstract}

Kata kunci: Daun pepaya (Carica papaya L.), kacang hijau (Vigna radiate L.), sediaan minuman serbuk instan

\begin{abstract}
Background: Breastmilk is an emulsion of fat in a solution of protein, lactose and organic salts secreted by the mother's breast glands as the baby's main food. Currently, many mothers give breast milk for less than six months due to several factors such as sick babies, tired work and stress, so that milk production is not smooth and others. Papaya leaves contain several important nutrients, several studies have been conducted, Entin (2002) proved that katuk leaves, bitter melon leaves, and papaya leaves are complementary plants which are traditional plants and have the potential to increase breast milk production4. Mung beans also contain active compounds, namely polyphenols and flavonoids which function to increase breast milk production hormones. organoleptic tests for three weeks using papaya (Carica papaya L.) and green beans (Vigna radiata L.) to facilitate the production of breast milk (ASI) by making it easy and practical.
\end{abstract}


Methods: This study used an action research design. Preparations with different sugar formulations, namely F1 5 grams of papaya leaves, 41.6 grams of green beans, 60 grams of sugar. F2 5 grams of papaya leaves, 41.6 grams of green beans, 90 grams of sugar. And F3 5 grams of papaya leaves, 41.6 grams of green beans, 120 grams of sugar. Samples are stored in the same storage, namely at room temperature $20-25^{\circ} \mathrm{C}$.

Results: It showed that the papaya and green bean instant powder drink dosage stored at room temperature $20-25^{\circ} \mathrm{C}$ had organoleptic stability of shape, odor, and color.

Conclusion: From the results of the organicoleptic test, 3 preparations with slightly different tastes were produced, one of which has a better taste, namely the taste is not too sweet and not too bitter. This preparation can last for three weeks with a relatively unchanged physical condition.

Keywords: Papaya leaves (Carica papaya L.), green beans (Vigna radiate L.), instant powder drink preparation

\section{PENDAHULUAN}

ASI (Air Susu Ibu) adalah suatu emulsi lemak dalam larutan protein, laktose dan garam-garam organik yang disekresi oleh kedua belah kelenjar payudara ibu, sebagai makanan utama bagi bayi. Sekarang ini banyak ibu yang memberikan ASI kurang dari enam bulan karena beberapa faktor seperti bayi sakit, lelah bekerja, stress, produksi ASI tidak lancar dan lain-lain. Daun pepaya mengandung beberapa nutrisi penting, beberapa penelitian yang membuktikan bahwa daun katuk, daun pare, dan daun pepaya merupakan suplemen yang merupakan tanaman tradisional dan memiliki potensi meningkatkan produksi air susu ibu [4]. Ternyata daun pepaya memiliki rerata tertinggi dibandingkan daun katuk dan daun pare karena pepaya lebih banyak mengandung vitamin dan kalium yang diperlukan untuk memenuhi kebutuhan ibu saat menyusui. Selain itu daun pepaya juga mengandung vitamin $\mathrm{E}$ yang tinggi. (Haryono Rudi, 2014; Kusumaningrum Istika Dwi, 2017)8. Pengolahannya dibuat menjadi serbuk daun pepaya yang lebih cepat diserap oleh tubuh dibandingkan dengan daun pepaya yang dimakan langsung, karena bentuk serbuk sudah berupa sari daun pepaya sehingga proses penyerapan dalam tubuh lebih cepat dibandingkan dimakan langsung. Daun pepaya dikenal dengan rasa yang sangat pahit, oleh karena itu agar dapat dikosumsi serta untuk menutupi rasa pahitnya maka penulis bermaksud menambahkan kacang hijau yang memiliki khasiat sama untuk memperlancar ASI. Kacang hijau banyak memiliki kandungan protein, mineral, kalsium, fosfor, lemak, vitamin B1 (tiamin) dan vitamin B2 (riboflavin) (Widayanti Elok, 2015)18. Sari kacang hijau mengandung Vitamin B1 (thiamin) yang berfungsi untuk mengubah karbohidrat menjadi energi, memperkuat sistem saraf dan bertanggung jawab untuk produksi ASI [17]. Kacang hijau juga mengandung senyawa aktif yaitu polifenol dan flavonoid yang berfungsi meningkatkan hormon produksi ASI

\section{METODE PENELITIAN}

Penelitian ini menggunakan disain penelitian tindakan (action research). Sediaan yang berupa 3 sampel di simpan dalam penyimpanan yang sama, yaitu dalam suhu ruangan $20-25^{\circ} \mathrm{C}$.

\section{HASIL DAN PEMBAHASAN PENELITIAN}

Pembuatan minuman serbuk instan dengan metode kristalisasi yang dilakukan selama 40 menit dengan diaduk secara terus menerus hingga berubah menjadi serbuk. Pengamatan menunjukan bahwa penelitian ini menghasilkan perbedaan organoleptik sediaan yang berbeda, yang dipengaruhi oleh jumlah gula, dan juga pada proses pembuatan saat pengambilan sediaan dari wajan masih ada beberapa yang menempel pada wajan dan blender 
sehingga jumlah sediaan yang diperoleh, jumlahnya menjadi berbeda pula.

Pada penelitian ini penulis berhasil membuat serbut instan untuk ketiga formula yang didisain yaitu F1, F2 dan F3. Adapun deskripsi organoleptiknya adalah sediaan F1 memiliki aroma yang paling kuat khas bau daun pepayanya, kemudian diikuti F2 dan F3. Demikian juga dari tampilan warna serbuk instan F1 berwarna hijau kecoklatan, F2 sedikit hijau kecoklatan dan F3 berwarna putih. Kemudian dari rasa F1 masih terdapat rasa pahit dilidah, sementara itu F2 dan F3 berasa manis. Sehingga secara organoleptis dari sediaan serbuk instan yang dibuat, formula F1 dan F2 lebih dapat diterima dari pada F1.
Perbedaan organoleptic dari ketiga formula ini secara jelas ditentukan oleh jumlah gula dalam setiap sediaan tersebut.

Pada tahap pengamatan dan refleksi yaitu melakukan pengamatan terhadap penelitian yang dikerjakan serta mencatat hasilnya dan menganalisis temuan yang didapatkan pada saat melakukan observasi. Untuk melihat hasil uji organoleptik dilakukan pengamatan selama 3minggu. Diamati 3(tiga) hari sekali. Pada uji organoleptik yang diamati yaitu bentuk, aroma, warna dan rasa. Sediaan yang berupa 3(tiga) sampel disimpan dalam penyimpanan yang sama, yaitu dalam suhu ruangan $20-25^{\circ} \mathrm{C}$.

Tabel 1 Hasil Uji Organoleptik Selama 3 Minggu

\begin{tabular}{|c|c|c|c|c|c|c|c|c|c|}
\hline \multicolumn{2}{|c|}{ Sampel } & \multicolumn{8}{|c|}{ Pengamatan hari ke - } \\
\hline Kode & Organo & 1 & 3 & 6 & 9 & 12 & 15 & 18 & 21 \\
\hline \multirow{10}{*}{ F1 } & $\mathrm{Bau}$ & $\begin{array}{c}\text { Khas } \\
\text { daun } \\
\text { pepaya }\end{array}$ & $\begin{array}{c}\text { Khas } \\
\text { daun } \\
\text { pepaya }\end{array}$ & $\begin{array}{c}\text { Khas } \\
\text { daun } \\
\text { pepaya }\end{array}$ & $\begin{array}{c}\text { Khas } \\
\text { daun } \\
\text { pepaya }\end{array}$ & $\begin{array}{c}\text { Khas } \\
\text { daun } \\
\text { pepaya }\end{array}$ & $\begin{array}{c}\text { Khas } \\
\text { daun } \\
\text { pepaya }\end{array}$ & $\begin{array}{c}\text { Khas } \\
\text { daun } \\
\text { pepaya }\end{array}$ & $\begin{array}{c}\text { Khas } \\
\text { daun } \\
\text { pepaya }\end{array}$ \\
\hline & Warna & Hijau & Hijau & Hijau & Hijau & Hijau & Hijau & Hijau & Hijau \\
\hline & & $\begin{array}{l}\text { kecokl } \\
\text { atan }\end{array}$ & $\begin{array}{c}\text { kecokla } \\
\text { tan }\end{array}$ & $\begin{array}{c}\text { kecoklat } \\
\text { an }\end{array}$ & $\begin{array}{c}\text { kecoklat } \\
\text { an }\end{array}$ & $\begin{array}{c}\text { kecoklat } \\
\text { an }\end{array}$ & $\begin{array}{c}\text { kecoklat } \\
\text { an }\end{array}$ & $\begin{array}{c}\text { kecoklat } \\
\text { an }\end{array}$ & $\begin{array}{c}\text { kecoklat } \\
\text { an }\end{array}$ \\
\hline & Rasa & Manis & Manis & Manis & Manis & Manis & Manis & Manis & Manis \\
\hline & & agak & agak & agak & agak & agak & agak & agak & agak \\
\hline & & pahit & pahit & pahit & pahit & pahit & pahit & pahit & pahit \\
\hline & $\mathrm{Bau}$ & Sedikit & Sedikit & Sedikit & Sedikit & Sedikit & Sedikit & Sedikit & Sedikit \\
\hline & & khas & khas & khas & khas & khas & khas & khas & khas \\
\hline & & daun & daun & daun & daun & daun & daun & daun & daun \\
\hline & & pepaya & pepaya & pepaya & pepaya & рерауа & рерауа & pepaya & рерауа \\
\hline \multirow[t]{5}{*}{$\mathrm{F} 2$} & Warna & Hijau & Hijau & Hijau & Hijau & Hijau & Hijau & Hijau & Hijau \\
\hline & & $\begin{array}{c}\text { kecokl } \\
\text { atan }\end{array}$ & $\begin{array}{c}\text { kecokla } \\
\text { tan }\end{array}$ & $\begin{array}{c}\text { kecoklat } \\
\text { an }\end{array}$ & $\begin{array}{c}\text { kecoklat } \\
\text { an }\end{array}$ & $\begin{array}{c}\text { kecoklat } \\
\text { an }\end{array}$ & $\begin{array}{c}\text { kecoklat } \\
\text { an }\end{array}$ & $\begin{array}{c}\text { kecoklat } \\
\text { an }\end{array}$ & $\begin{array}{c}\text { kecoklat } \\
\text { an }\end{array}$ \\
\hline & Rasa & Manis & Manis & Manis & Manis & Manis & Manis & Manis & Manis \\
\hline & Bau & Sedikit & Sedikit & Sedikit & Sedikit & Sedikit & Sedikit & Sedikit & Sedikit \\
\hline & & khas & khas & khas & khas & khas & khas & khas & khas \\
\hline \multirow[t]{4}{*}{ F3 } & & daun & daun & daun & daun & daun & daun & daun & daun \\
\hline & & pepaya & pepaya & pepaya & pepaya & pepaya & pepaya & pepaya & pepaya \\
\hline & Warna & Putih & Putih & Putih & Putih & Putih & Putih & Putih & Putih \\
\hline & Rasa & Manis & Manis & Manis & Manis & Manis & Manis & Manis & Manis \\
\hline
\end{tabular}

Berdasarkan hasil pengamatan yang tertera pada Tabel 1 menunjukan hasil uji organoleptik sediaan minuman serbuk instan daun pepaya (Carica papaya L.) dan kacang hijau (Vigna radiata L.) yang telah diuji dan diamati selama 3 minggu, pengamatan dilakukan setiap 3 hari sekali. Pengamatan uji organoleptik meliputi bau, warna dan rasa. Data tersebut merupakan hasil pembuatan minuman serbuk instan dengan metode kristalisasi yang dilakukan selama 40 menit dengan diaduk secara terus menerus hingga berubah menjadi serbuk. Pengamatan uji organoleptik dengan formulasi yang berbeda dalam suhu yang sama. 
Pengamatan organoleptik selama tiga minggu berturut-berturut dapat disimpulkan bahwa hasil pengujian organoleptik yang dilakukan peneliti dalam suhu $20-25^{\circ} \mathrm{C}$ tidak timbul perubahan yang signifikan dalam hal bentuk sediaan, warna, rasa, dan bau. Hal ini terjadi dikarenakan dari proses pengambilan, penyiapan bahan serta proses pembuatan yang mengikuti tahapnya dengan benar, maka dari itu tidak adanya perubahan negatif dalam sediaan yang dibuat.

\section{Gambar 4.1 Grafik Hasil Uji Kesukaan}

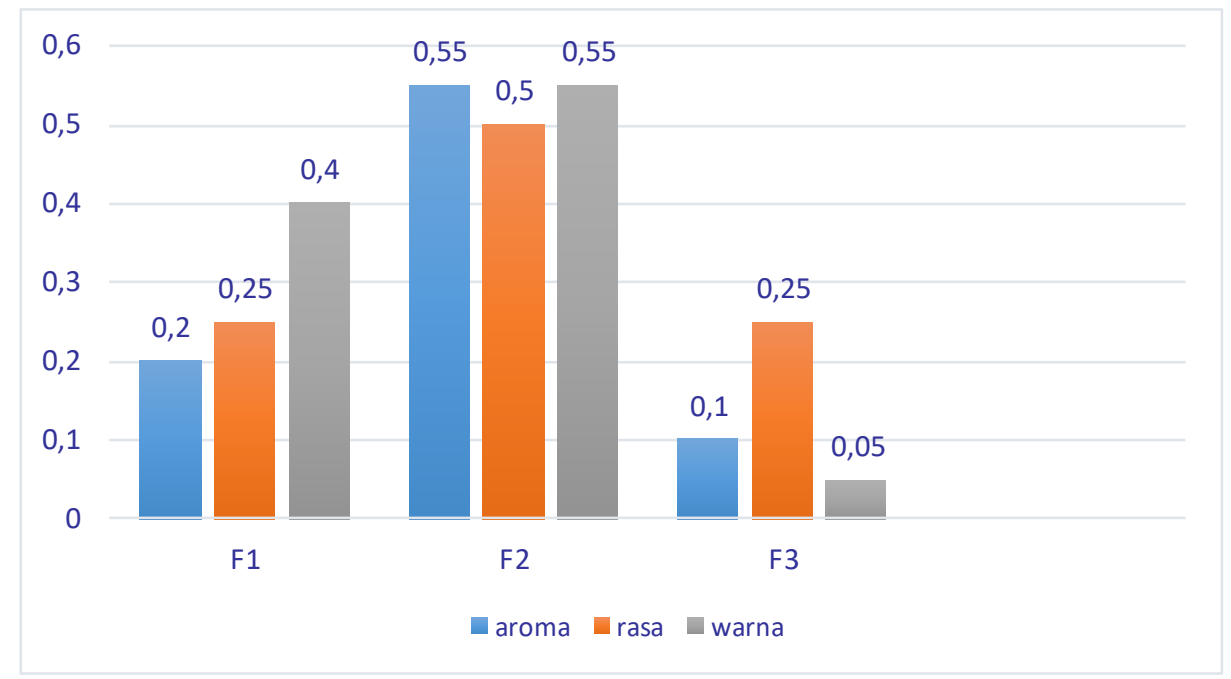

Berdasarkan hasil pengamatan yang tertera pada Tabel 4.2 menunjukan hasil uji kesukaan 20 responden terhadap sediaan minuman serbuk instan daun pepaya (Carica papaya L.) dan kacang hijau (Vigna radiata L.) untuk memperlancar produksi Air Susu Ibu (ASI). Dari ke tiga formula responden banyak yang memilih rasa,

\section{SIMPULAN}

Dari hasil pengujian orgnaloleptik dihasilkan 3 sediaan dengan rasa yang sedikit berbeda salah satunya mempunyai rasa yang cukup enak yaitu rasanya tidak terlalu manis serta tidak terlalu pahit sediaan ini dapat bertahan selama tiga minggu dengan keadaan fisik yang relatif tidak berubah. Sediaan serbuk instan ini dibuat untuk melancarkan produsi ASI pada ibu menyusui dengan konsentrasi daun pepaya 5 gram, kacang hijau 41,6 gram, gula

\section{DAFTAR PUSTAKA}

1. Aprilia, R., Rilyani, R., \& Arianti, L. (2020). Pengaruh pemberian sayur daun pepaya terhadap kelancaran produksi ASI pada ibu nifas. Wellness and Healthy Magazine, 2(1), 5-12. warna, aroma untuk F2 yaitu dengan gula 90gr karena F2 memiliki rasa manis yang pas, aroma daun pepaya yang tidak terlalu kuat baunya, dan warna yang tidak terlalu hijau membuat responden tidak berpikir bahwa daun pepaya memiliki rasa yang pahit dan bau yang kuat.

putih 90 gram. Sampel dilarutkan dengan air suhu $90^{\circ} \mathrm{C}-120^{\circ} \mathrm{C}$. Hasil uji kesukaan menunjukan bahwa formulasi yang banyak disukai yaitu formulasi yaitu formulasi 2 dengan komposisi daun pepaya 5 gram, kacang hijau 41,6 gram, gula putih 90 gram dikarenakan aroma khas daun pepaya tidak tercium kuat karena sudah tertutup dengan aroma kacang hijau, rasa manis yang pas tidak terlalu manis dan warna yang tidak terlalu pekat dengan warna daun pepaya.

2. Ayuni, Renata. (2012). Khasiat Selangit Daun-Daun Ajaib Tumpas Beragam Penyakit. Yogyakarta.

3. Departemen Kesehatan RI. (1995). Farmakope Indonesia, Edisi IV. 
Direktorat Pengawan Obat dan Makanan. Jakarta.

4. Entin, W. (2002). Kinetika Fermentabilitas Daun Katuk (Sauropus androgynus L. Merr), Daun Pare (Momordica charantia L.), dan Daun Pepaya (Caricia pepaya L.) di dalam Rumen Sapi. Skripsi, Jurusan Ilmu Nutrisi dan Makanan Ternak, Fakultas Peternakan, Institut Pertanian Bogor

5. Haryono Rudi, (2014). Manfaat Asi Eksklusif Untuk Buah Hati Anda.

6. Hart, E., \& Bond, M. (2000). Using action research. Using evidence in health and social care. London: Sage, 86-107.

7. Kristiyansari, Weni. (2009). ASI, Menyusui dan SADARI. Yogjakarta: Nuha Medika

8. Kusumaningrum, I. D. (2019). Potensi Daun Pepaya (Carica Papaya L) Sebagai Alternatif Memperlancar Produksi ASI. Surya Medika: Jurnal Ilmiah Ilmu Keperawatan dan Ilmu Kesehatan Masyarakat 12.2.

9. Pitaloka, D. A., Abrory, R., \& Pramita, A. D. (2018). Hubungan antara Pengetahuan dan Pendidikan Ibu dengan Pemberian ASI Eksklusif di Desa Kedungrejo Kecamatan Waru Kabupaten Sidoarjo.

10. Reni, (2014). Payudara dan Laktasi. Jakarta: Salemba medika.

11. Rengga, P. W. D., \& Handayani A. P., (2004). Serbuk Instan Manis Daun Pepaya Sebagai Upaya Mempelancar Air Susu Ibu. Jurnal Fakultas Teknik Kimia. Semarang: Universitas Negeri Semarang.

12. Ritonga, N. J., et al. (2019). Sari Kacang Hijau Sebagai Alternatif Meningkatkan Produksi Air Susu Ibu (ASI) Pada Ibu Menyusui. Jurnal Keperawatan Dan Fisioterapi (JKF) $2.1: 89-94$.

13. Siagian, D. S., \& Sara, H. (2019). Analisis Hubungan Pemberian ASI Eksklusif dan Pendidikan Ibu terhadap Perkembangan Bayi. Jurnal Kesmas Asclepius 1, no. 2: 96-105.

14. Suksesty, Catur Erty \& Marthia, I.
(2017). Pengaruh Jus Campur Kacang Hijau Terhadap Peningkatan Hormon Prolaktin dan Berat Badan Bayi. Universitas Muhammadiyah Tanggerang. Jurnal Ilmiah bidan Vol.11.no.3.2017.

15. Turlina, L., \& Wijayanti, L. (2015). Pengaruh Pemberian Serbuk Daun Pepaya Terhadap Kelancaran ASI Pada Ibu Nifas Di Bpm. Kedungpring Kabupaten Lamongan. Jurnal Media Komunikasi Ilmu Kesehatan, 7, 01.

16. Wibowo, L., \& Evi, F. (2012). Pengolahan Rumput Laut (Eucheuma Cottoni) Menjadi Serbuk Minuman Instan. Jurusan Ilmu Kelautan dan Perikanan, Politeknik Negeri Pontianak Jl. A. Yani Pontianak 78124.

17. Widia, L, dan Putri, A. S. (2019). Efektivitas Konsumsi Sari Kacang HIjau (Vigna Radiate) Terhadap Kelancaran Produksi ASI Ibu Nifas. Jurnal Darul Azhar, 7(1), 23-30.

18. Widayanti, E. (2015). Tanaman untuk Pelancar ASI di Sekitar Kita. Jawa Tengah: Kementrian Kesehatan Badan Penelitian dan Pengembangan Kesehatan Badan Penelitian dan Pengembangan Tanaman Obat dan Obat Tradisional.

19. Widyastuty, Kiky. (2014). Pengaruh Konsumsi Sari Kacang Hijau Terhadap Produksi Air Susu Ibu (ASI) pada Ibu Menyusui di Wilayah Kerja Puskesmas Dinoyo Malang. http://eprints.umm.ac.id/id/e print/25931

20. Wulandari, D. T., \& Siti R. J. (2015). Pengaruh Pemberian Sari Kacang Hijau pada Ibu Nifas dengan Kelancaran Produksi ASI di BPM Yuni Widaryanti, Amd.Keb Sumber Mulyo Jogoroto Jombang; Universitas Pesantren Tinngi Draul'Ulum Jombang. Jurnal EDU Health, Vol.5 no.2, September 2015.

21. WHO. (2011). Exclusive breastfeeding Exclusive breastfeeding for six months best for babies everywhere, http://www.who.int/mediacentre/ne ws/statements/2011/breastfeeding0 
110115/ en/index.html

22. Yuliantoro, N. (2019). Inovasi Cheescake Menggunakan Bahan Kacang Buncis Sebagai Pengganti Terigu. Jurnal Media Wisata: Wahana Informasi Pariwisata, 17 (1).

23. Zulkarnain, Zuraida, et al. (2012). Pengaruh Formula Jamu Untuk Meningkatkan Volume ASI. Jawa Tengah: Balai Besar Penelitian dan Pengembangan Tanaman Obat dan Obat Tradisional Badan Penelitian dan Pengembangan Kesehatan

Kementerian Kesehatan. 